\title{
Antioxidant and Free Radical-Scavenging Activity of Choto-san and Its Related Constituents
}

\author{
Pramote Mahakunakorn, Michihisa Tohda, Yukihisa Murakami, Kinzo Matsumoto, and \\ Hiroshi WATANABE* \\ Department of Pharmacology, Institute of Natural Medicine, Toyama Medical and Pharmaceutical University; 2630 \\ Sugitani, Toyama 930-0194, Japan. Received June 10, 2003; accepted September 16, 2003
}

\begin{abstract}
The antioxidant properties of Choto-san and its related constituents such as Chotoko and Choto-san without Chotoko, and phenolic compounds contained in Chotoko such as epicatechin, caffeic, acid and quercetin were evaluated. In the 1,1-diphenyl-2-picrylhydrazyl (DPPH) radical-scavenging assay, the scavenging activity of Chotoko (IC $\left.\mathrm{IC}_{50} 14.3 \mu \mathrm{g} / \mathrm{ml}\right)$ was found to be higher than that of Choto-san (IC $\left.{ }_{50} 206.2 \mu \mathrm{g} / \mathrm{ml}\right)$ and Choto-san without Chotoko $\left(\mathrm{IC}_{50} 244.3 \mu \mathrm{g} / \mathrm{ml}\right)$. Epicatechin $\left(\mathrm{IC}_{50} 10.4 \mu \mathrm{M}\right)$, caffeic acid $\left(\mathrm{IC}_{50} 13.8 \mu \mathrm{M}\right)$, and quercetin $\left(\mathrm{IC}_{50}\right.$ $7.1 \mu \mathrm{M})$ also revealed scavenging activity against DPPH radicals. Choto-san $\left(\mathrm{IC}_{50} 67.7 \mu \mathrm{g} / \mathrm{ml}\right)$ exhibited stronger inhibitory activity against superoxide anion formation than Choto-san without Chotoko (IC ( $\left._{50} 92.4 \mu \mathrm{g} / \mathrm{ml}\right) \mathrm{but}$ weaker activity than Chotoko $\left(\mathrm{IC}_{50} 18.3 \mu \mathrm{g} / \mathrm{ml}\right)$. The generation of superoxide anion was also inhibited by epicatechin $\left(\mathrm{IC}_{50} 175.2 \mu \mathrm{M}\right)$, caffeic acid $\left(\mathrm{IC}_{50} 141.7 \mu_{\mathrm{M}}\right)$, and quercetin $\left(\mathrm{IC}_{50} 18.7 \mu_{\mathrm{M}}\right)$. In a hydroxyl radical-scavenging experiment, Choto-san ( $\left.\mathrm{IC}_{50} 2.4 \mathrm{mg} / \mathrm{ml}\right)$, Chotoko (IC $\left.\mathrm{IC}_{50} 2.2 \mathrm{mg} / \mathrm{ml}\right)$, Choto-san without Chotoko (IC $\left.{ }_{50} 2.8 \mathrm{mg} / \mathrm{ml}\right)$, epicatechin ( $\left(\mathrm{IC}_{50} 3.9 \mathrm{~mm}\right)$, caffeic acid $\left(\mathrm{IC}_{50} 3.6 \mathrm{~mm}\right)$, and quercetin (IC $\left.\mathrm{IC}_{50} 1.9 \mathrm{~mm}\right)$ exhibited activity. In NG108-15 cells, when added simultaneously with $\mathrm{H}_{2} \mathrm{O}_{2}(500 \mu \mathrm{M})$, Choto-san $(250 \mu \mathrm{g} / \mathrm{ml})$, Chotoko $(250 \mu \mathrm{g} / \mathrm{ml})$, Choto-san without Chotoko $(500 \mu \mathrm{g} / \mathrm{ml})$, epicatechin $(200 \mu \mathrm{M})$, caffeic acid $(200 \mu \mathrm{M})$, and quercetin $(200 \mu \mathrm{M})$ effectively protected cells from oxidative damage. In conclusion, the present results provide evidence that Choto-san acts as an antioxidant and cytoprotective agent against oxidative damage, which is due at least partly to the phenolic compounds contained in Chotoko.
\end{abstract}

Key words Choto-san; Chotoko; oxidative stress; free radical; antioxidant; NG108-15 cell

Oxidative stress resulting from the toxic effects of free radicals on tissue plays an important role in the pathogenesis of various neurodegenerative diseases such as Alzheimer's disease, Parkinson's disease, and ischemic-reperfusion injury. $^{1-3)}$ The inhibition of such free radical-mediated pathophysiology has become a central focus for research afforts designed to prevent or ameliorate tissue injury, and number of studies have been performed to discover antioxidants from natural products or medicinal plants for the prevention or treatment of free radical-induced neurodegenerative diseases. Choto-san, a Kampo medicine, has long been administered to aged patients with headache, dizziness, vertigo, tinnitus, and shoulder stiffness in China and Japan. It has been reported that Choto-san was effective in the treatment of vascular dementia in a clinical study ${ }^{4)}$ and also showed a protective effect against transient cerebral ischemia-induced cognitive impairment in mice. ${ }^{5)}$ However, the mechanisms of protection remain unclear. A number of studies have suggested a strong correlation between spatial cognitive impairment and the generation of reactive oxygen species. $^{6-8)}$ The medicinal plant Chotoko, the hooks of Uncaria sp., is contained in Choto-san as the main component herb. The Uncaria genus was determined to have antioxidant and free radical-scavenging activities using the electron spin resonance technique ${ }^{9)}$ and to have antilipid peroxidation activity in the brain of iron-induced epileptic rats. ${ }^{10)}$ Recently, the inhibitory effects of Choto-san and hooks and stems of Uncaria sinensis on free radical-induced lysis of rat red blood cells have been reported. ${ }^{11)}$ Phytochemical studies revealed that Chotoko is rich in phenolic compounds such as epicatechin, caffeic acid, and quercetin. ${ }^{12,13)}$ Generally, these phenolic compounds are potent antioxidants and free radical scavengers. We therefore speculated that Choto-san might improve vascular dementia and prevent transient ischemia-induced damage of brain function in mice, at least in part due to its antioxidant activities. Hence the present study was performed to investigate the antioxidant effects of Choto-san and its related constituents such as Chotoko and Choto-san without Chotoko as well as its phenolic components; epicatechin, caffeic acid, and quercetin.

\section{MATERIALS AND METHODS}

Materials The following reagents were purchased from the indicated sources. Medicinal herbs comprising Choto-san from Tochimoto (Osaka, Japan) and the extract were prepared as described previously. ${ }^{14)}$ Aminopterin, epicatechin, caffeic acid, $\alpha$-tocopherol (vitamin E), and 1,1-diphenyl-2picrylhydrazyl (DPPH) were from Sigma Chemical Co. (St. Louis, MO, U.S.A.); curcumin, quercetin, EDTA, and mannitol from Nacalai Tesque, Inc. (Kyoto, Japan); ferrozine from Dojin Co. (Kumamoto, Japan); 2-deoxyribose, phenazine methosulfate (PMS), superoxide dismutases, nitroblue tetrazolium (NBT), NADH, 2-thiobarbituric acid (TBA), 1,1,3,3tetramethoxypropane from Wako Pure Chemical (Osaka, Japan); $\mathrm{H}_{2} \mathrm{O}_{2}(30 \% \mathrm{w} / \mathrm{v})$ from Santoku Chemical Industries Co. (Tokyo, Japan); thymidine and hypoxanthine from Kohjin Co. (Tokyo, Japan); minomycin from Lederle (Japan); Dulbecco's modified Eagle's medium (DMEM) from Gibco BRL, Life Technologies, Inc. (New York, U.S.A.); and fetal bovine serum (FBS) from Canasera International, Inc. (Canada). All other chemicals were of the highest analytical grade and purchased from common sources.

Animals Eight-week-old $30-40 \mathrm{~g}$ male ICR mice (SLC, Shizuoka, Japan) were subjected to a $12: 12-\mathrm{h}$ light: dark cycle (lights on 07:30-19:30). All experimental 
procedures were performed in accordance with standards established by the Guide for the Care and Use of Laboratory Animals of Toyama Medical and Pharmaceutical University.

Cell Cultures NG108-15 cells were continuously cultured using the method described previously, ${ }^{15)}$ with minor modifications. ${ }^{16)}$ Briefly, the cells were cultured in DMEM supplemented with 4\% FBS, hypoxanthine $(100 \mu \mathrm{M})$, thymidine $(16 \mu \mathrm{M})$, aminopterin $(1 \mu \mathrm{M})$, and minomycin $(1 \mu \mathrm{g} / \mathrm{ml})$. The culture medium was changed every $2-3 \mathrm{~d}$. All cultures were maintained at $37^{\circ} \mathrm{C}$ under $10 \% \mathrm{CO}_{2}$ with $95 \%$ relative humidity. For experiments, cells were plated onto $3.5-\mathrm{cm}$ polyornithine-coated plates and used after $3-4 \mathrm{~d}$ of incubation.

$\mathrm{H}_{2} \mathrm{O}_{2}$-Induced Oxidative Cell Damage in NG108-15 Cells Choto-san, Chotoko, and Choto-san without Chotoko were dissolved in sterile water. Epicatechin, quercetin, and caffeic acid were first dissolved in dimethyl sulfoxide (DMSO) and later mixed with the culture medium to give a final DMSO concentration of $0.5 \% \mathrm{v} / \mathrm{v}$. DMSO was also present at this level in control cells not treated with test compounds. To induce cell damage, the cells were incubated in culture medium containing $\mathrm{H}_{2} \mathrm{O}_{2} 500 \mu \mathrm{M}$ and $0.05 \%$ trypan blue dye with or without various concentrations of test compounds for $3 \mathrm{~h}$. Then cell viability was measured using the trypan blue dye-exclusion method and expressed as the percentage of unstained cells among total cells. In the cell viability test, curcumin, a natural antioxidant isolated from Curcuma longa, was used as a reference standard. ${ }^{16)}$

Inhibition of Lipid Peroxidation Male ICR mouse brains were quickly removed and washed with ice-cold normal saline. The brain tissue was homogenized in 19 volumes of ice-cold $5 \mathrm{~mm}$ potassium phosphate buffer $(\mathrm{pH}$ 7.4) using a glass homogenizer. The protein content in the tissue homogenate was measured using the Biuret method. The inhibition of lipid peroxidation activity was determined by quantification of thiobarbituric acid-reactive substance (TBARS) using the slightly modified method of Buege and Aust. ${ }^{17)}$ The reaction mixture was composed of tissue homogenate $0.5 \mathrm{ml}$, phosphate buffer (50 ms, pH 7.4) $0.9 \mathrm{ml}, 0.01 \mathrm{~mm} \mathrm{FeSO}_{4}+$ $0.1 \mathrm{~mm}$ ascorbic acid $0.5 \mathrm{ml}$, and $0.1 \mathrm{ml}$ of vehicle or test compounds. The reaction mixtures were incubated at $37^{\circ} \mathrm{C}$ for $30 \mathrm{~min}$ and the reaction was terminated on ice by adding $0.5 \mathrm{ml}$ of $35 \%(\mathrm{v} / \mathrm{v})$ perchloric acid to the mixture. After centrifugation at $3000 \mathrm{~g}$ for $15 \mathrm{~min}$, the supernatant was incubated with $0.5 \mathrm{ml}$ of $0.6 \%$ thiobarbituric acid at $100{ }^{\circ} \mathrm{C}$ for $15 \mathrm{~min}$. After a cooling period, TBARS generated were spectrophotometrically determined at $532 \mathrm{~nm}$ using MDA as a standard.

Assay of DPPH Radical-Scavenging Activity To measure antioxidant activity, the DPPH radical-scavenging assay was carried out according to the procedure described previously ${ }^{18)}$ with a slight modification. Briefly, the DPPH radicalscavenging activity was measured in a reaction mixture containing $1 \mathrm{~mm}$ DPPH radical solution $0.1 \mathrm{ml}, 99 \%$ ethanol $0.8 \mathrm{ml}$, and $0.1 \mathrm{ml}$ of sample solution. The solution was rapidly mixed and scavenging capacity was measured spectrophotometrically by monitoring the decrease in absorbance at $517 \mathrm{~nm}$. The antioxidant activity of test compounds was expressed as $\mathrm{IC}_{50}$, which was defined as the concentrations of test compounds required for inhibition of the formation of DPPH radicals by $50 \%$. Vitamin $E$ was used as a positive control.

Assay of Superoxide Radical-Scavenging Activity Superoxide radicals were determined using spectrophotometric measurement of the effects of various concentrations of test compounds on the reduction of NBT according to a previously described procedure. ${ }^{19)}$ Superoxide radicals were generated in a nonenzymatic phenazine methosulfate-nicotinamide adenine dinucleotide (PMS/NADH) system. The nonenzymatic generation of superoxide radicals was measured in reaction mixtures containing various concentrations of test compounds, PMS $(15 \mu \mathrm{M})$, NADH $(73 \mu \mathrm{M})$, and NBT $(50 \mu \mathrm{M})$ in phosphate buffer $(20 \mathrm{~mm}, \mathrm{pH} 7.4)$. After incubation for $5 \mathrm{~min}$ at ambient temperature, the color was read at $560 \mathrm{~nm}$ against blank samples. The superoxide radical-scavenging activity was expressed as the $\mathrm{IC}_{50}$ value. Superoxide dismutase enzyme (SOD) was used as a positive control.

Scavenging of Hydroxyl Radicals The formation of hydroxyl radicals $\left(\mathrm{OH}^{*}\right)$ from Fenton reagents was quantified using 2-deoxyribose oxidative degradation as described previously. ${ }^{20)}$ The principle of the assay is the quantification of the 2-deoxyribose degradation product, malonaldehyde, by its condensation with TBA. The reaction mixture contained deoxyribose $(2.8 \mathrm{~mm}) ; \mathrm{FeCl}_{3}(100 \mu \mathrm{M}) ; \mathrm{KH}_{2} \mathrm{PO}_{4}-\mathrm{KOH}$ buffer (20 mM, pH 7.4); EDTA (100 $\mu \mathrm{M}) ; \mathrm{H}_{2} \mathrm{O}_{2}(1.0 \mathrm{~mm})$; ascorbic acid $(100 \mu \mathrm{M})$, and various concentrations of the test compounds in a final volume of $1 \mathrm{ml}$. Ferric chloride and EDTA (when added) were premixed just before addition to the reaction mixture. The reaction mixture was incubated at $37^{\circ} \mathrm{C}$ for $60 \mathrm{~min}$. After incubation at $37^{\circ} \mathrm{C}$ for $1 \mathrm{~h}, 1.0 \mathrm{ml}$ of $2.8 \%$ trichloroacetic acid and $1.0 \mathrm{ml}$ of $0.6 \%$ aqueous solution of TBA were added to $0.5 \mathrm{ml}$ of sample; test tubes were heated at $95{ }^{\circ} \mathrm{C}$ for $15 \mathrm{~min}$ to develop the color. After a cooling period, TBARS formation was measured spectrophotometrically at $532 \mathrm{~nm}$ against an appropriate blank. The hydroxyl radical-scavenging activity was determined by comparing absorbance of the control with that of test compounds.

The hydroxyl radical-scavenging activity was expressed as the $\mathrm{IC}_{50}$ value. In this experiment, all test compounds were dissolved in $\mathrm{KH}_{2} \mathrm{PO}_{4}-\mathrm{KOH}$ buffer $(20 \mathrm{~mm}$, $\mathrm{pH}$ 7.4). Epicatechin, caffeic acid, and quercetin are poorly soluble in aqueous solution at $\mathrm{pH}$ 7.4. Therefore their preparation was in alkaline solution and then the $\mathrm{pH}$ was adjusted to 7.4 immediately before use. The effect of the test compounds on hydroxyl radical-induced deoxyribose degradation was also examined in the absence of EDTA. Mannitol, a classical $\mathrm{OH}^{*}$ scavenger, was used as the reference standard.

Iron Chelating Activity To evaluate test compound-iron interaction further, we also performed the ferrozine test, which assesses the capability to interact with iron(II), preventing the formation of the complex between the reduced metal form and the specific $\mathrm{Fe}^{2+}$ colorimetric detector ferrozine. The chelation of ferrous ions by Choto-san and its related constituents and by the standard molecules was carried out according to the method reported previously. ${ }^{21)}$ Briefly, different concentrations of test compounds $(0.1 \mathrm{ml})$ were added to a solution of $50 \mu \mathrm{M}$ of $\mathrm{FeSO}_{4}(0.1 \mathrm{ml})$ and $0.7 \mathrm{ml}$ of $0.15 \mathrm{M} \mathrm{NaCl}$ solution. The reaction was initiated by the addition of ferrozine $300 \mu \mathrm{M}(0.1 \mathrm{ml})$ and the mixture was shaken vigorously and left standing at room temperature for $10 \mathrm{~min}$. Absorbance of the solution was then measured spectrophotometrically at $562 \mathrm{~nm}$ in a spectrophotometer. EDTA was used 
as a positive control. All tests were run in triplicate and averaged.

Statistical Analysis All results are expressed as mean \pm S.D. The statistical significance of differences between groups was determined by one-way analysis of variance (ANOVA), followed by Dunnett's test for multiple comparisons among groups. Differences of $p<0.05$ were considered statistically significant.

\section{RESULTS}

$\mathrm{H}_{2} \mathrm{O}_{2}$-Induced Oxidative Cell Damage in NG108-15 Cells NG108-15 cells were treated with various concentrations of $\mathrm{H}_{2} \mathrm{O}_{2}(100,250,500$, or $750 \mu \mathrm{M})$. Following $3 \mathrm{~h}$ of incubation after $\mathrm{H}_{2} \mathrm{O}_{2}$ challenge, cell viability was determined. The results showed that $\mathrm{H}_{2} \mathrm{O}_{2}$ significantly reduced cell viability in a concentration-dependent manner with an $\mathrm{IC}_{50}$ value of about $500 \mu \mathrm{M}$. At this concentration, the cell viability was about $55 \%$ of the control viability (Fig. 1). Therefore, for subsequent protection experiments, we used $500 \mu \mathrm{M}$ as the concentration of $\mathrm{H}_{2} \mathrm{O}_{2}$. When curcumin, a reference standard, was added simultaneously with $\mathrm{H}_{2} \mathrm{O}_{2}$, it caused a concentration-dependent increase in cell viability from 25 to $100 \mu \mathrm{M}$ (Fig. 1A). When Choto-san $(250 \mu \mathrm{g} / \mathrm{ml})$, Chotoko $(250 \mu \mathrm{g} / \mathrm{ml})$, Choto-san without Chotoko $(500 \mu \mathrm{g} / \mathrm{ml})$, epicatechin $(200 \mu \mathrm{M})$, caffeic acid $(200 \mu \mathrm{M})$, or quercetin $(200 \mu \mathrm{M})$ were added together with $\mathrm{H}_{2} \mathrm{O}_{2}$, they significantly increased the viability of NG108-15 cells in a concentrationdependent manner compared with treatment with $\mathrm{H}_{2} \mathrm{O}_{2}$ alone (Figs. 1B, C). In the present study, we used DMSO as a solvent for curcumin and phenolic compounds of Chotoko. DMSO is recognized as having relatively effective hydroxyl
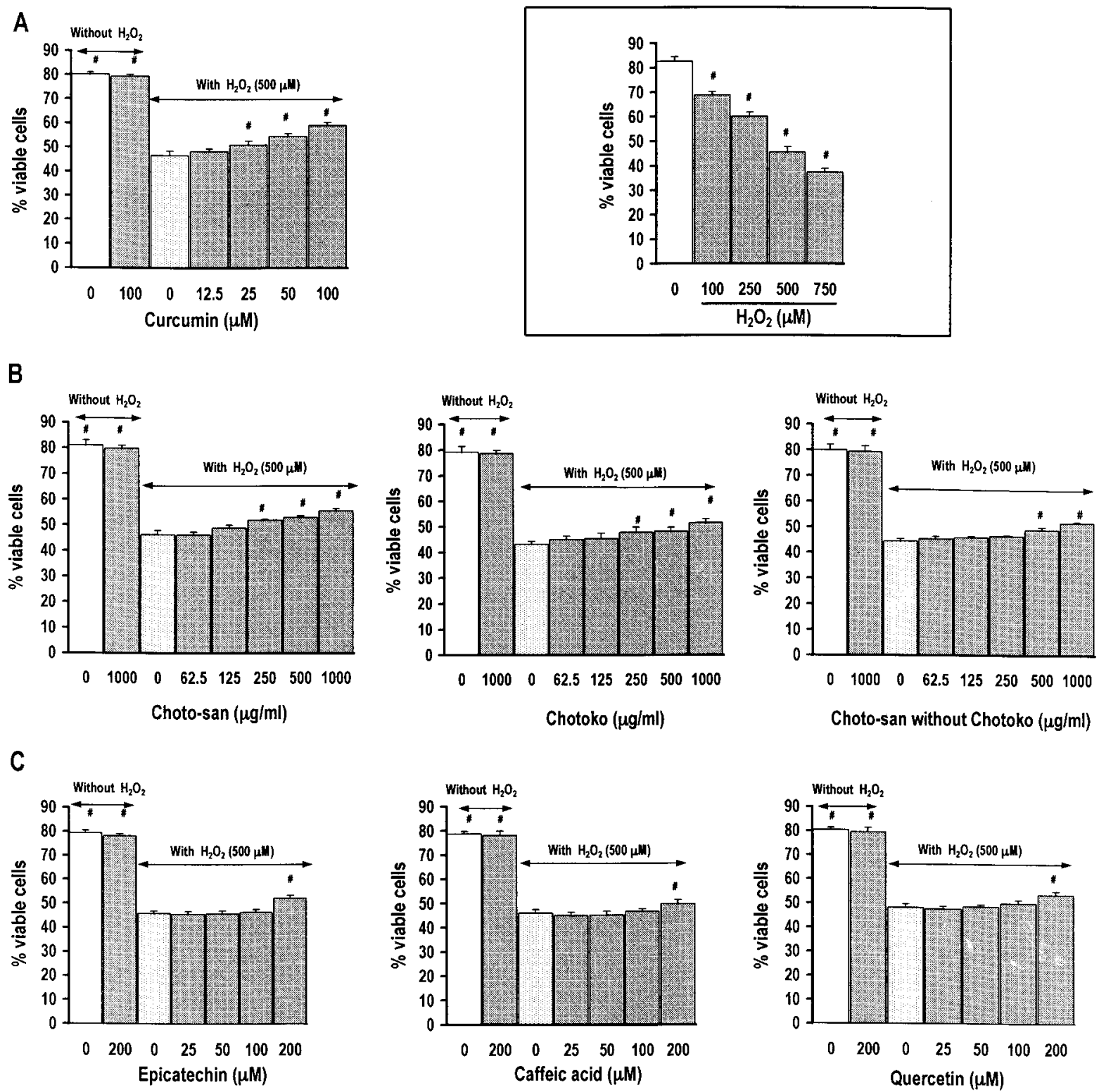

Fig. 1. Effects of Test Compounds on $\mathrm{H}_{2} \mathrm{O}_{2}$-Induced Cell Damage in NG108-15 Cells When Added with $\mathrm{H}_{2} \mathrm{O}_{2}$

NG108-15 cells were treated with $\mathrm{H}_{2} \mathrm{O}_{2}(500 \mu \mathrm{M})$ together with various concentrations of test compounds: (A) a reference drug, curcumin, (B) Choto-san, Chotoko, and Chotosan without Chotoko, (C) phenolic compounds contained in Chotoko (epicatechin, caffeic acid, and quercetin). Inset: $\mathrm{H}_{2} \mathrm{O}_{2}$-induced reduction of viability of NG108-15 cells when treated with various concentrations of $\mathrm{H}_{2} \mathrm{O}_{2}(100,250,500,750 \mu \mathrm{M})$. After $3 \mathrm{~h}$ of incubation, cell viability was measured using the trypan blue dye exclusion method. Data are expressed as mean \pm S.D. $(n=3-4)$. \# $p<0.05$ compared with the $\mathrm{H}_{2} \mathrm{O}_{2}$-treated control group. 


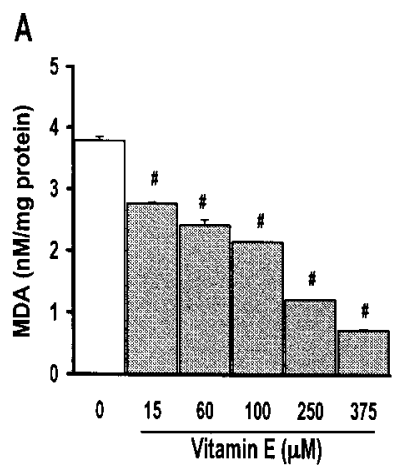

B
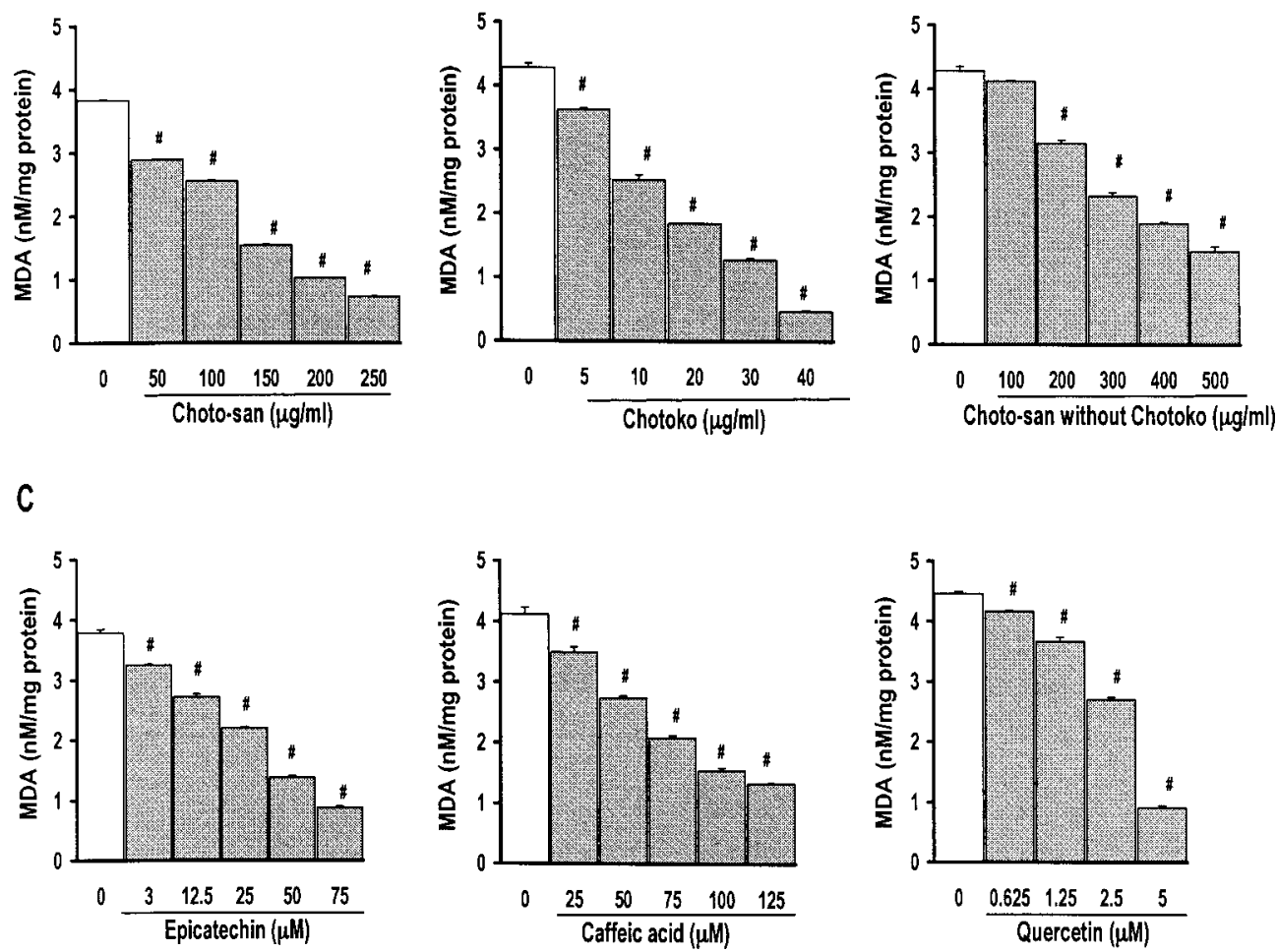

Fig. 2. Effects of Test Compounds on $\mathrm{Fe}^{2+}$-Ascorbate-Induced Lipid Peroxidation in Brain Homogenate

The reaction mixture was composed of tissue homogenate, phosphate buffer ( $50 \mathrm{~mm}, \mathrm{pH} 7.4$ ), $0.01 \mathrm{~mm} \mathrm{FeSO}_{4}+0.1 \mathrm{~mm}$ ascorbic acid, and various concentrations of test compounds: (A) a reference drug, vitamin E, (B) Choto-san, Chotoko, and Choto-san without Chotoko, (C) phenolic compounds contained in Chotoko (epicatechin, caffeic acid, and quercetin). After $30 \mathrm{~min}$ of incubation, TBARS formation was measured spectrophotometrically at $532 \mathrm{~nm}$. All data are expressed as mean \pm S.D. $(n=3-4)$. $\# p<0.05$ compared with the vehicle-treated control group.

radical-scavenging activity. Removal of free radicals by DMSO may contribute to the protective effect of test compounds. To minimize the effect of DMSO and to demonstrate the actual effects of test compounds, the concentration of DMSO that we added to our cultures was relatively low: $0.5 \% \mathrm{v} / \mathrm{v}$ final concentration. Our preliminary results revealed that this concentration of DMSO had no effect on cell viability and did not show any protective effect against $\mathrm{H}_{2} \mathrm{O}_{2}$ induced oxidative damage in NG108-15 cells in all of the experiments (data not shown).

Inhibition of Lipid Peroxidation As shown in Fig. 2A, vitamin E, a reference drugs, exhibited a concentration-dependent suppressive effect on the lipid peroxidation caused by the radical-generating system in mice brain homogenate with an $\mathrm{IC}_{50}$ value of $153.7 \mu \mathrm{M}$. Choto-san, Chotoko, and Choto-san without Chotoko significantly inhibited the forma- tion of TBARS in brain homogenates in a concentration-dependent manner (Fig. 2B). The suppressive effect on the lipid peroxidation of Chotoko was found to be the most potent $\left(\mathrm{IC}_{50} 19.1 \mu \mathrm{g} / \mathrm{ml}\right)$, followed by Choto-san $\left(\mathrm{IC}_{50} 124.7 \mu \mathrm{g} / \mathrm{ml}\right)$, and Choto-san without Chotoko ( $\left.\mathrm{IC}_{50} 368.6 \mu \mathrm{g} / \mathrm{ml}\right)$. Phenolic compounds, epicatechin, caffeic acid, and quercetin also showed a significant suppressive effect on TBARS formation in brain tissue homogenate (Fig. 2C). Their respective $\mathrm{IC}_{50}$ values were $39.3,82.9$, and $3.1 \mu \mathrm{M}$.

DPPH Radical-Scavenging Activity The free radicalscavenging activity of Choto-san and its related constituents was also tested by their ability to bleach the stable radical $\mathrm{DPPH}$. This assay provided information on the reactivity of the compounds with a stable free radical. Because of the odd electron, DPPH shows a strong absorption band at $517 \mathrm{~nm}$ in visible spectroscopy (deep violet color). As this electron be- 
A
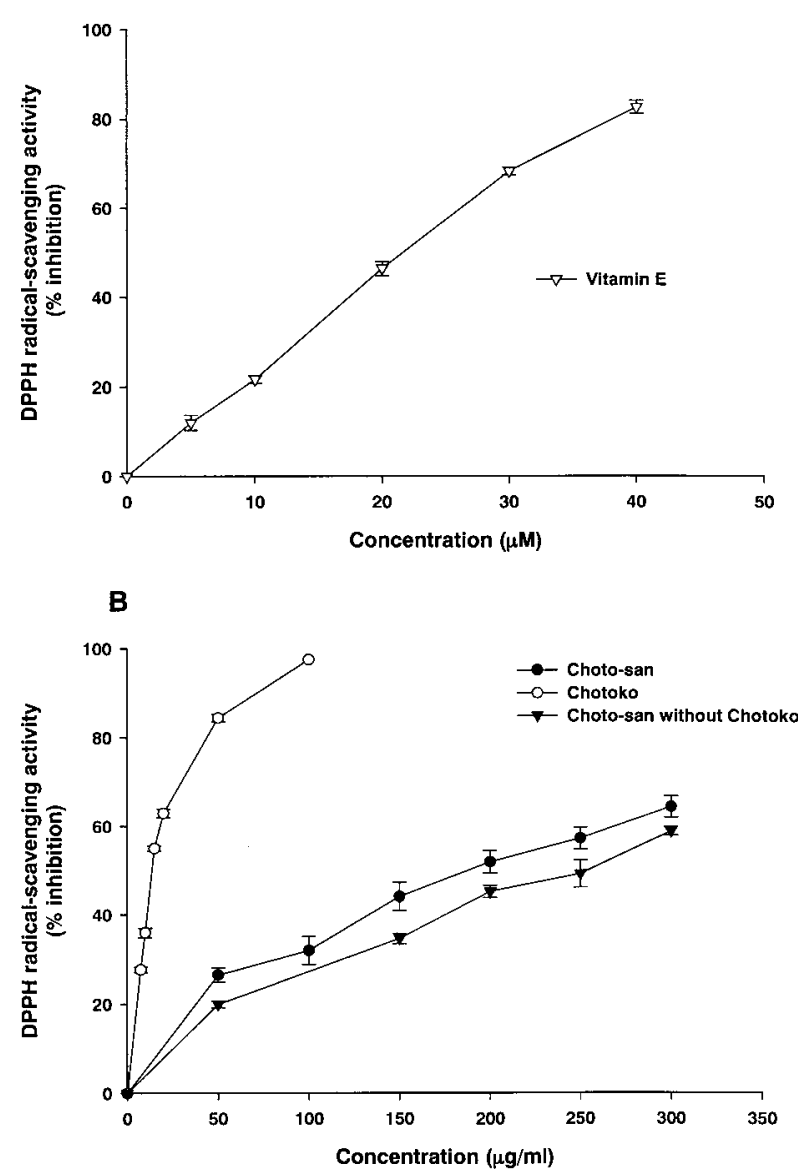

Fig. 3. DPPH Radical-Scavenging Activity of the Test Compounds

The reaction mixture contained $0.1 \mathrm{ml}$ of $1 \mathrm{~mm}$ DPPH radical solution, $0.8 \mathrm{ml}$ of $99 \%$ ethanol, and $0.1 \mathrm{ml}$ of test compounds (A) a reference drug, vitamin $\mathrm{E}$ and (B) Chotosan, Chotoko, and Choto-san without Chotoko. The solution was rapidly mixed and scavenging capacity was measured spectrophotometrically by monitoring the decrease in absorbance at $517 \mathrm{~nm}$. All data are expressed as mean \pm S.D. $(n=4)$ of the inhibition of DPPH radical (\% inhibition).

comes paired off in the presence of a free radical scavenger, the absorption vanishes, and the resulting decolorization is stoichiometric with respect to the number of electrons taken up. Vitamin E, a reference drug, exhibited scavenging activity with $\mathrm{IC}_{50}$ value of $24.5 \mu \mathrm{M}$ (Fig. 3A). Choto-san, Chotoko, and Choto-san without Chotoko also exhibited a DPPH radical-scavenging effect (Fig. 3B). In this test Chotoko ( $\mathrm{IC}_{50} 14.3 \mu \mathrm{g} / \mathrm{ml}$ ) was more efficient than Choto-san $\left(\mathrm{IC}_{50} 206.2 \mu \mathrm{g} / \mathrm{ml}\right)$ and Choto-san without Chotoko $\left(\mathrm{IC}_{50}\right.$ $244.3 \mu \mathrm{g} / \mathrm{ml})$. The phenolic compounds epicatechin, caffeic acid, and quercetin also revealed scavenging activity on DPPH radicals (data not shown) with $\mathrm{IC}_{50}$ values of 10.4 , 13.8 , and $7.1 \mu \mathrm{M}$, respectively.

Superoxide Anion Radical-Scavenging Activity The phenazine methosulphate-NADH mixture at $\mathrm{pH} 7.4$ generates superoxide anions, which can be measured by its ability to reduce NBT measured as an increase in absorbance change. The generation of superoxide anions was markedly inhibited by superoxide dismutase (SOD) with an $\mathrm{IC}_{50}$ value of 3.5 units $/ \mathrm{ml}$ (Fig. 4A). Choto-san, Chotoko, and Choto-san without Chotoko inhibited superoxide anion formation in a concentration-dependent manner (Fig. 4B), but Chotoko showed more potent scavenging activity $\left(\mathrm{IC}_{50} 18.3 \mu \mathrm{g} / \mathrm{ml}\right)$,
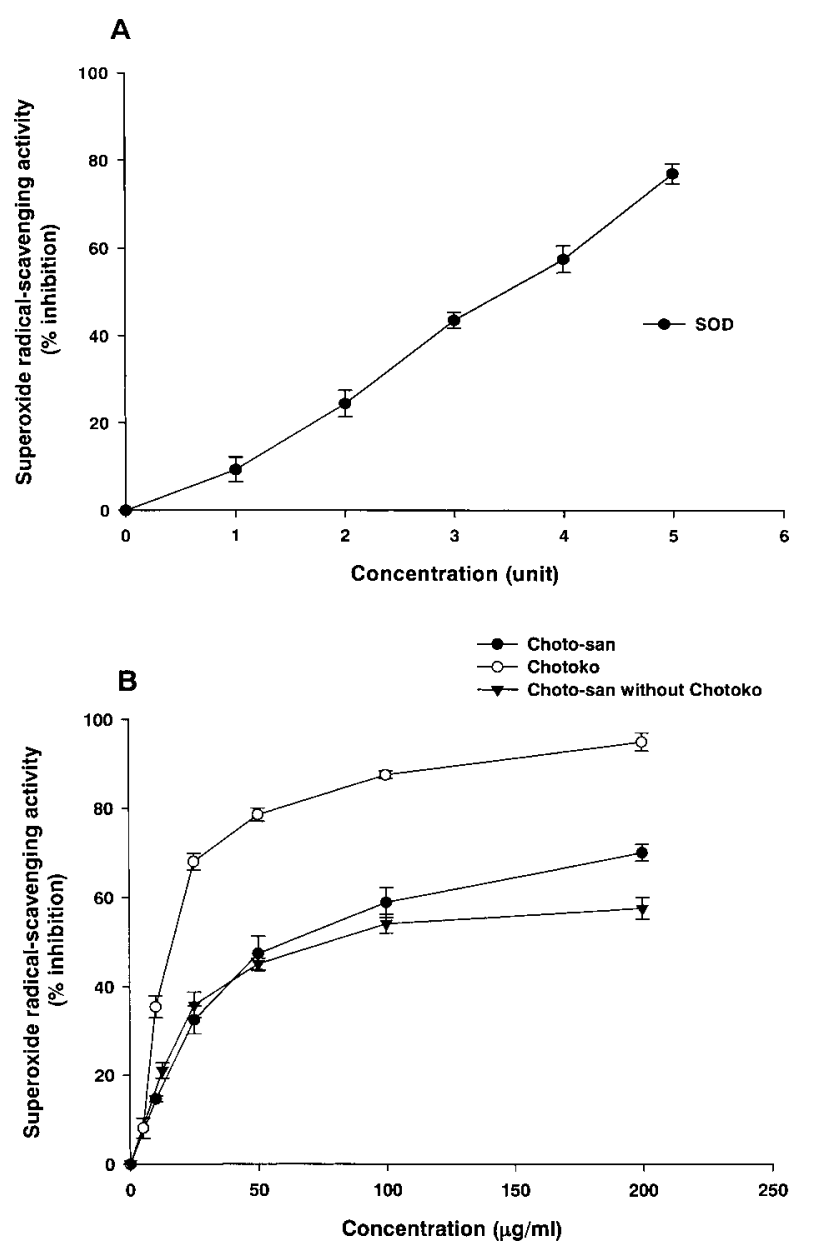

Fig. 4. Scavenging Activity of the Test Compounds on Superoxide Radicals Generated by the PMS/NADH System

The generation of superoxide radicals was measured in reaction mixtures containing PMS $(15 \mu \mathrm{M})$, NADH $(73 \mu \mathrm{M})$, and NBT $(50 \mu \mathrm{M})$ in phosphate buffer $(20 \mathrm{mM}, \mathrm{pH} 7.4)$, and various concentrations of test compounds (A) a reference drug, SOD and (B) Choto-san, Chotoko, and Choto-san without Chotoko. After incubation for $5 \mathrm{~min}$ at ambient temperature, the color formation was read at $560 \mathrm{~nm}$ against blank samples. All data are expressed as mean \pm S.D. $(n=4)$ of the inhibition of superoxide radical ( $\%$ inhibition).

followed by Choto-san $\left(\mathrm{IC}_{50} 67.7 \mu \mathrm{g} / \mathrm{ml}\right)$, and Choto-san without Chotoko ( $\left.\mathrm{IC}_{50} 92.4 \mu \mathrm{g} / \mathrm{ml}\right)$, respectively. The superoxide-induced NBT reduction was also effectively prevented by epicatechin, caffeic acid, and quercetin (data not shown). Their respective $\mathrm{IC}_{50}$ values were $175.2,141.7$, and $18.7 \mu \mathrm{M}$.

Hydroxyl Radical-Scavenging Activity This assay shows the ability of Choto-san and its related constituents to inhibit hydroxyl radical-mediated deoxyribose degradation in a reaction mixture with or without EDTA. The relative extents of inhibition of deoxyribose degradation will give an indication of $\mathrm{OH}^{-}$-scavenging and/or iron-chelating activities. In the presence of EDTA, mannitol, a classical $\mathrm{OH}^{*}$ scavenger, significantly inhibited deoxyribose degradation in a concentration-dependent manner with an $\mathrm{IC}_{50}$ value of $4.6 \mathrm{~mm}$ (Fig. 5A). Choto-san, Chotoko, and Choto-san without Chotoko also suppressed deoxyribose degradation in a concentration-dependent manner (Fig. 5B). The inhibitory activity was observed in the following order: Chotoko $\left(\mathrm{IC}_{50}\right.$ $2.2 \mathrm{mg} / \mathrm{ml})>$ Choto-san $\left(\mathrm{IC}_{50} 2.4 \mathrm{mg} / \mathrm{ml}\right)>$ Choto-san without Chotoko $\left(\mathrm{IC}_{50} 2.8 \mathrm{mg} / \mathrm{ml}\right)$. The phenolic compounds, epicatechin, caffeic acid, and quercetin had an inhibitory effect on 
EDTA (+)

A

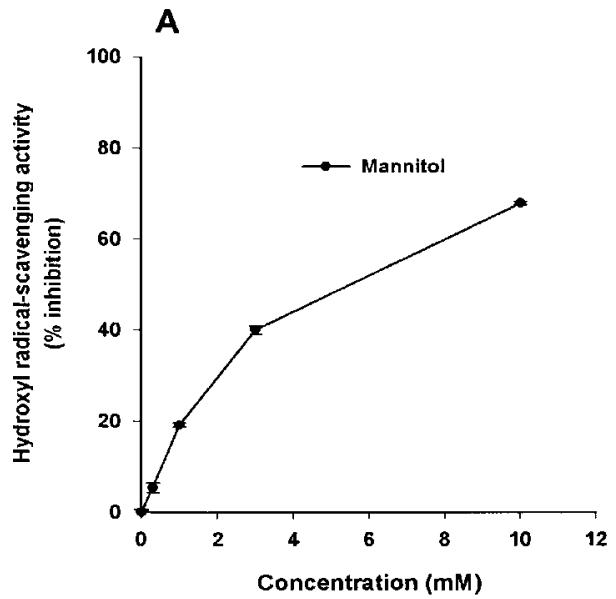

B

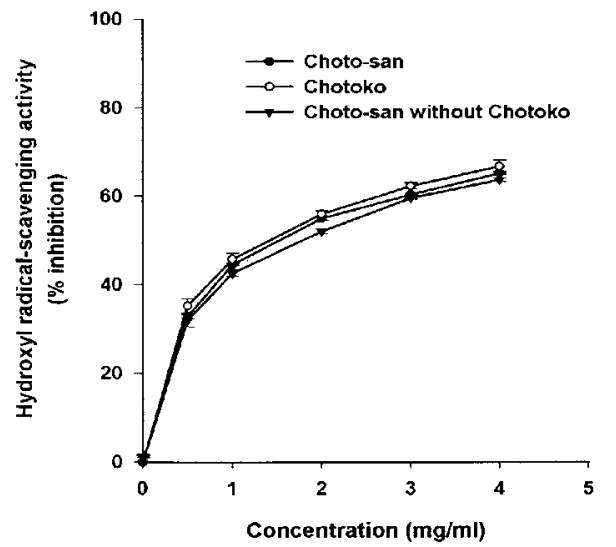

EDTA (-)

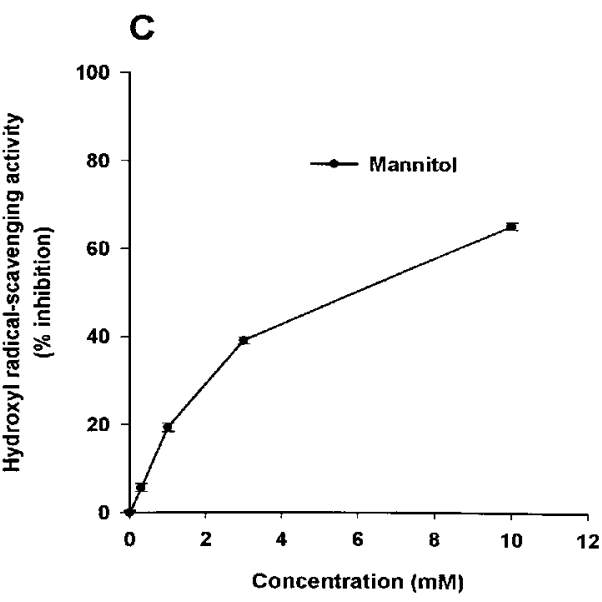

D

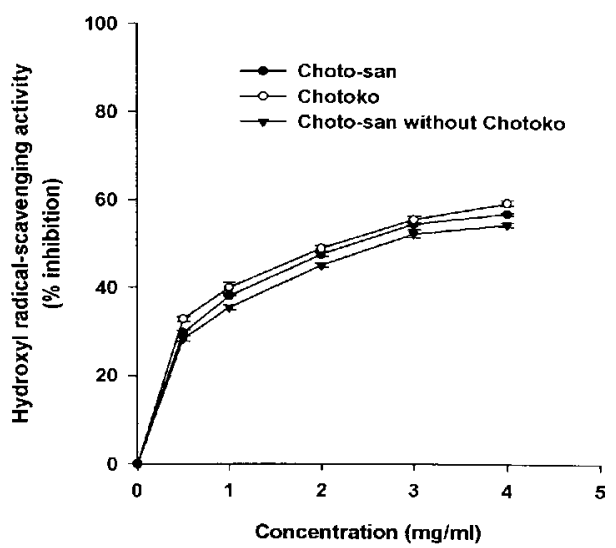

Fig. 5. Hydroxyl Radical-Scavenging Activity of the Test Compounds in the Presence (EDTA(+)) and Absence (EDTA(-)) of EDTA

The reaction mixture in a final volume of $1 \mathrm{ml}$ contained $20 \mathrm{~mm} \mathrm{KH}_{2} \mathrm{PO}_{4}-\mathrm{KOH}$ (buffer $\mathrm{pH} 7.4$ ), 2.8 mм deoxyribose, $\mathrm{FeCl}_{3} 100 \mu \mathrm{M}$, EDTA $100 \mu \mathrm{M}$ (when added), 1 mм $\mathrm{H}_{2} \mathrm{O}_{2}$, or compounds tested (A and C) a reference drug, mannitol and (B and D) Choto-san, Chotoko, and Choto-san without Chotoko. The reaction was triggered by the addition of ascorbic acid $100 \mu \mathrm{M}$. After incubation for $60 \mathrm{~min}$ at $37^{\circ} \mathrm{C}$, deoxyribose degradation extent was measured using the TBA method, reading the absorbance at $532 \mathrm{~nm}$. The hydroxyl radicalscavenging activity values represent the percentage of inhibition of deoxyribose degradation. The data are expressed as mean \pm S.D. $(n=4)$.

deoxyribose degradation (data not shown). Their respective $\mathrm{IC}_{50}$ values were $3.9,3.6$, and $1.9 \mathrm{~mm}$. In the absence of EDTA, mannitol still exhibited suppressive action against deoxyribose degradation with an $\mathrm{IC}_{50}$ value of $4.7 \mathrm{~mm}$ (Fig. 5C). Choto-san, Chotoko, and Choto-san without Chotoko also showed an inhibitory effect on deoxyribose degradation (Fig. 5D). The inhibitory activity was observed in the following order: Chotoko ( $\left.\mathrm{IC}_{50} 1.3 \mathrm{mg} / \mathrm{ml}\right)>$ Choto-san $\left(\mathrm{IC}_{50}\right.$ $1.4 \mathrm{mg} / \mathrm{ml})>$ Choto-san without Chotoko $\left(\mathrm{IC}_{50} 1.6 \mathrm{mg} / \mathrm{ml}\right)$. The phenolic compounds, epicatechin, caffeic acid, and quercetin still showed suppressive actions on deoxyribose degradation (data not shown) with respective $\mathrm{IC}_{50}$ values of 2.7, 4.4, and $1.4 \mathrm{~mm}$. The $\mathrm{IC}_{50}$ of Choto-san and its related constituents in the absence of EDTA was markedly lower than that observed in the presence of EDTA. These data suggest that the iron-chelating effect of test compounds may be involved in the inhibition of deoxyribose degradation by Choto-san and its related constituents.

Iron-Chelating Activity The chelating of ferrous ions by Choto-san and its related constituents was evaluated by the inhibition of ferrozine- $\mathrm{Fe}^{2+}$ complex formation. Ferrozine quantitatively forms complexes with $\mathrm{Fe}^{2+}$. In the presence of chelating agents, complex formation is disrupted, with the result that the violet color of the complex is reduced.
Our results demonstrated that the formation of ferrozine$\mathrm{Fe}^{2+}$ complex is not complete in the presence of the test compounds (Fig. 6). The formation of ferrozine- $\mathrm{Fe}^{2+}$ complex was decreased concentration dependently by Choto-san, Chotoko, and Choto-san without Chotoko. Chotoko was found to be the most potent with an $\mathrm{IC}_{50}$ value of $1.3 \mathrm{mg} / \mathrm{ml}$, followed by Choto-san ( $\left.\mathrm{IC}_{50} 1.4 \mathrm{mg} / \mathrm{ml}\right)$ and Choto-san without Chotoko ( $\mathrm{IC}_{50} 1.6 \mathrm{mg} / \mathrm{ml}$ ). In the same way, epicatechin, caffeic acid, and quercetin also inhibited ferrozine- $-\mathrm{Fe}^{2+}$ complex formation with $\mathrm{IC}_{50}$ values of $1.2 \mathrm{~mm}, 6.9 \mathrm{~mm}$, and $169.6 \mu \mathrm{M}$, respectively.

\section{DISCUSSION}

We investigated the possible antioxidant properties of Choto-san and its related constituents because such actions may contribute to explaining their therapeutic effect in vascular dementia and transient cerebral ischemia. First, we evaluated the protective effect of Choto-san and its related constituents on $\mathrm{H}_{2} \mathrm{O}_{2}$-induced cell damage in NG108-15 cells. When added simultaneously with $\mathrm{H}_{2} \mathrm{O}_{2} 500 \mu \mathrm{M}$, Choto-san and its related constituents significantly protected NG108-15 cells against $\mathrm{H}_{2} \mathrm{O}_{2}$-induced cell damage in a concentrationdependent manner, compared with treatment with $\mathrm{H}_{2} \mathrm{O}_{2}$ 

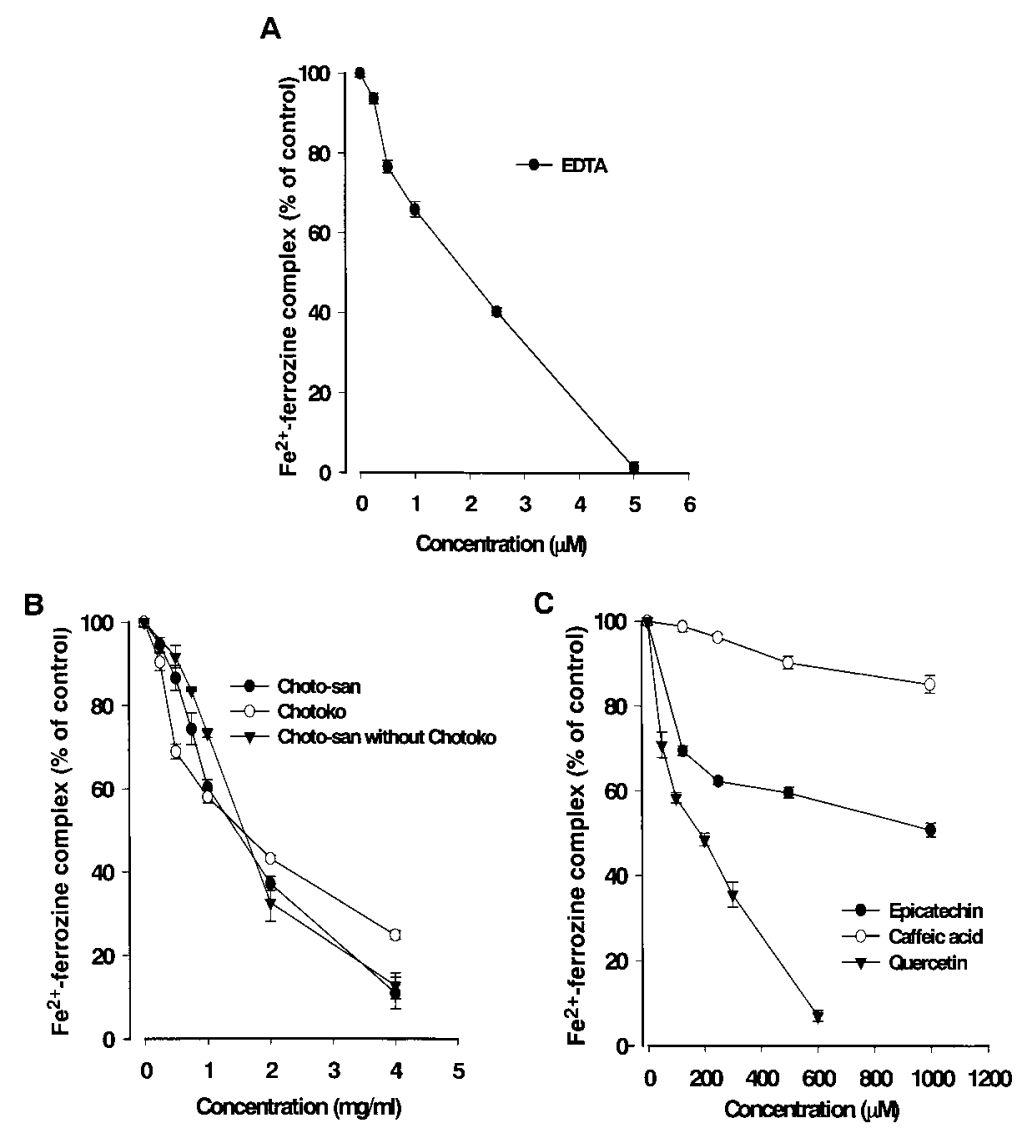

Fig. 6. Interaction of the Test Compounds with Iron(II) Evaluated by Drug Inhibition of Fe ${ }^{2+}$-Ferrozine Complex Formation

Experimental mixtures contained $\mathrm{FeSO}_{4} 5 \mu \mathrm{M}$ and ferrozine $30 \mu \mathrm{M}$ with or without various concentrations of test compounds: (A) a reference drug, EDTA, (B) Choto-san, Chotoko, and Choto-san without Chotoko, (C) phenolic compounds contained in Chotoko (epicatechin, caffeic acid, and quercetin), in 0.15 $\mathrm{m}$ NaCl. Data are expressed as mean \pm S.D. $(n=4)$

alone. Hydrogen peroxide formed by two-electron reduction of $\mathrm{O}_{2}$ is not a free radical but is an oxidizing agent. In the presence of $\mathrm{O}_{2}$ and transition metal ions, $\mathrm{H}_{2} \mathrm{O}_{2}$ can generate $\mathrm{OH}^{\cdot}$ via Fenton reaction. In addition, $\mathrm{H}_{2} \mathrm{O}_{2}$ can easily cross the cell membrane and exerts injurious effects on tissues through a number of different mechanisms, such as perturbing intracellular calcium homeostasis, ${ }^{22)}$ decreasing intracellular ATP, ${ }^{23)}$ inducing DNA damage, ${ }^{24)}$ and inducing apoptosis. ${ }^{25)}$ Several previous studies have reported the neuroprotective effect of antioxidant and/or free radical-scavenging compounds against $\mathrm{H}_{2} \mathrm{O}_{2}$-induced cell damage in various assay systems. $^{26-28)}$ Thus the antioxidants appear to have a close relation with the neuroprotective effect.

It is possible that the protective effect of Choto-san and its related constituents against the $\mathrm{H}_{2} \mathrm{O}_{2}$-induced decrease in cell viability may at least partly result from its antioxidant and free radical-scavenging properties. To test this possibility, the antioxidant and free radical-scavenging activities of the test compounds were investigated. To clarify the mode of the protective effect of Choto-san and its related constituents against oxidative stress-induced cell damage, in vitro lipid peroxidation experiments were carried out. The inhibition of lipid peroxidation has been used as a model to elucidate antioxidant activity. According to the results obtained, Choto-san and its related compounds significantly inhibited the $\mathrm{Fe}^{2+}$ ascorbic acid-stimulated lipid peroxidation in the brain homogenate. It is generally thought that the inhibition of lipid peroxidation by Choto-san and its related constituents may be due to their free radical-scavenging activities. Superoxide indirectly initiates lipid peroxidation because superoxide anion acts as a precursor of singlet oxygen and $\mathrm{OH}^{\cdot}{ }^{29)} \mathrm{Hy}-$ droxyl radicals eliminate hydrogen atoms from the membrane lipid, which results in lipid peroxidation. To explain whether the inhibitory effects of Choto-san and its related constituents on lipid peroxidation and the protective effect on $\mathrm{H}_{2} \mathrm{O}_{2}$-induced cell damage was due to the scavenging of free radicals, it is essential to evaluate whether these compounds are able to scavenge the free radicals using various assay systems such as the DPPH radical-scavenging, superoxide radical-scavenging, and hydroxyl radical-scavenging assay.

The free radical-scavenging activity of Choto-san and its related constituents was also evaluated based on their ability to quench the synthetic DPPH radical. This assay provides information on the reactivity of test compounds with a stable free radical. The bleaching of DPPH absorption is representative of the capacity of test compounds to scavenge free radicals independently from any enzymatic activity. Our results clearly demonstrated that Choto-san and its related constituents were as effective as $\alpha$-tocopherol in scavenging DPPH radicals.

It is well known that superoxide anions damage biomacromolecules directly or indirectly by forming $\mathrm{H}_{2} \mathrm{O}_{2}, \mathrm{OH}^{*}$, peroxylnitrile, or singlet oxygen during pathophysiologic events such as ischemic-reperfusion injury. The superoxide radical- 
scavenging activity of Choto-san and its related constituents were also evaluated based on their ability to quench the superoxide radical generated from the PMS/NADH reaction. This assay provides information on the reactivity of test compounds with superoxide free radicals, independently of any enzymatic activity. All the compounds under investigation showed superoxide radical-scavenging activity.

The hydroxyl radical is a highly potent oxidant that reacts with almost all biomolecules found in living cells. The deoxyribose assay allows determination of rate constants of reactions with $\mathrm{OH}^{*}$ and assessment of abilities to chelate metal ion. In this model system, a mixture of $\mathrm{FeCl}_{3}-$ EDTA and $\mathrm{H}_{2} \mathrm{O}_{2}$ is incubated with deoxyribose in phosphate buffer $(\mathrm{pH}$ 7.4). Deoxyribose is degraded by $\mathrm{OH}^{*}$ generated by Fenton systems and results in a series of reactions during which MDA is formed and may be detected by its ability to react with TBA to form a pink chromogen. ${ }^{30)}$

Consequently, the ability to diminish the amount of color formation has been adapted as one measurement of antioxidative properties. In the absence of EDTA, iron ions are equally available to both the deoxyribose and the test compound. Thus compounds that are able to chelate iron preferentially and present the resulting metal complex in a less redox-active form compared with EDTA-metal complex will protect deoxyribose against damage in the presence of ascorbate and $\mathrm{H}_{2} \mathrm{O}_{2}$. Substances that inhibit deoxyribose degradation in the assay are also able to bind iron ions sufficiently strongly to remove them from deoxyribose. Thus EDTA removes iron ions from deoxyribose, but iron-EDTA chelates are very effective in generating $\mathrm{OH}^{*}$ so that the deoxyribose is still degraded by $\mathrm{OH}^{*}$ in solution, rather than by $\mathrm{OH}$ formed on the deoxyribose molecule. Studies using the deoxyribose assay can provide useful information on the likelihood that molecules could chelate iron ions in a way that prevents them from catalyzing $\mathrm{OH}^{*}$ formation. Thus when iron is added to the assay mixture as ferric chloride instead of as ferric-EDTA, some of the $\mathrm{Fe}^{3+}$ ions bind to deoxyribose, and damage to the sugar becomes site specific so that the $\mathrm{OH}^{\text {* }}$ formed by bound iron ions immediately attacks the deoxyribose. The ability of a substance to inhibit deoxyribose degradation under these reaction conditions is a measure of its ability to chelate metal ion. ${ }^{31,32)}$

Choto-san and its related constituents exhibited an inhibitory effect on hydroxyl radical-induced deoxyribose degradation in both the presence and absence of EDTA. Thus our results suggest that Choto-san and its related constituents are not only effective scavengers of $\mathrm{OH}^{*}$ in this system but also iron chelators. To clarify this possibility, we examined the iron-chelating effect of the test compounds in the ferrozine test that provided information regarding the reactivity of the test compounds with iron and we found that Choto-san and its related constituents interfered with the formation of ferrous-ferrozine complex, suggesting that they have marked iron-chelating activities and capture ferrous ion before ferrozine. It is possible that the antioxidant effect of Choto-san and its related constituents may at least in part result from its iron-chelating activities. In the present study, three classic free radical-scavenging tests were carried out and our results clearly demonstrated that both Choto-san and Chotoko exhibited potent free radical-scavenging activity. On the basis of $\mathrm{IC}_{50}$ values, Chotoko was 14.4 times more potent than
Choto-san in the DPPH assay and 3.7 times more potent than Choto-san in the superoxide radical assay. However, in the hydroxyl radical-scavenging assay, Chotoko was only 1.1 times more potent than Choto-san. The inconsistency of Chotoko and Choto-san in their relative radical-scavenging capacity against the different radicals tested may be explained by the different mechanisms involved in the radicalantioxidant reactions in different systems. There are some fundamental differences between the three assays. First, the features of the free radicals such as their redox potentials or stability are not the same. These factors may be involved in the radical-antioxidant reactions. The scavenging effect on DPPH radicals and superoxide radicals represent direct radical-scavenging activity. However, in the hydroxyl radicalscavenging assay, hydroxyl radicals are generated by the Fenton reaction and the inhibition of deoxyribose degradation could be attributed to the inhibition of radicals or the $\mathrm{Fe}^{2+}$ chelating effect of the test compounds. Other factors such as the stereoselectivity of the radicals or solubility of the test compounds in different assay systems may also affect the capacity of test compounds to react and quench different radicals. Based on its better suppressive effect on lipid peroxidation and higher free radical-scavenging activity in our cellfree assays, Chotoko would have been expected to be superior to Choto-san in inhibiting oxidative damage induced by $\mathrm{H}_{2} \mathrm{O}_{2}$ in NG108-15 cells, but this was not the case. Despite being weaker than Chotoko in the inhibition of lipid peroxidation and free radical-scavenging activity, Choto-san was as potent as Chotoko in protecting against oxidative cell damage induced by $\mathrm{H}_{2} \mathrm{O}_{2}$ at the same concentration range (250$1000 \mathrm{mg} / \mathrm{ml}$ ). Thus the protective effect of Choto-san and Chotoko against $\mathrm{H}_{2} \mathrm{O}_{2}$-induced oxidative damage in NG10815 cells is not directly correlated with their suppressive effect on lipid peroxidation and their free radical-scavenging activity in homogeneous solution. It has been reported that many antioxidants interact with and are incorporated into biomembranes. ${ }^{33,34)}$ Presumably, the protective effect may depend not only on their antioxidant activity but also on their affinity with and permeability through cell membranes. Polyphenolic compounds are widely distributed in plants. Many phenolic compounds have been shown to have biological actions, including antioxidant activity. ${ }^{27,35,36)}$ Our present results clearly demonstrate that epicatechin, caffeic acid, and quercetin exhibit antioxidant effects, free radical-scavenging activity, and cytoprotective effects against oxidative stress. Chotoko, the main medicinal plant in Choto-san, also contains many phenolic compounds including epicatechin, caffeic acid, and quercetin. ${ }^{12,13)}$ Previous studies have reported the antioxidant and free radical-scavenging activities of Chotoko. ${ }^{9,10)} \mathrm{Re}$ cently, the inhibitory effects of Choto-san and the hooks and stems of $U$. sinensis on free radical-induced lysis of rat red blood cells have been reported. ${ }^{11)}$ The present results confirm the antioxidant properties of this medicinal plant and these effects were attributed to their phenolic constituents. All Kampo medicines under investigation exhibit antioxidant activity but Chotoko showed more potent antioxidant activity than Choto-san and Choto-san without Chotoko. Moreover, Choto-san also showed higher antioxidant activity than Choto-san without Chotoko. From these results, it can be suggested that Chotoko plays an important role in the antioxidant activity of Choto-san. In conclusion, our study provides 
the evidence that Choto-san has antioxidant and cytoprotective properties, which are at least partly due to the phenolic compounds contained in Chotoko.

Acknowledgments This work was supported by Grantsin-Aid for Leading Research Utilizing the Potential of Regional Science and Technology from the Ministry of Education, Culture, Sports, Science and Technology, Japan. The authors are grateful to Professor Haruhiro Higashida, Department of Biophysical Genetics, Molecular Medicine and Biotransformatics, Kanazawa University Graduate School of Medicine, Japan, for the gift of NG108-15 neuroblastomaglioma hybrid cells.

\section{REFERENCES}

1) Dexter D. T., Carter C. J., Wells F. R., Javoy-Agid F., Agid Y., Lees A., Jenner P., Marsden C. D., J. Neurochem., 52, 381-389 (1989).

2) Halliwell B., Gutterridge J. M. C., Cross C. E., J. Lab. Clin. Med., 119, 598-620 (1992).

3) Beal M. F., Ann. Neurol., 38, 357-366 (1995).

4) Itoh T., Shimada Y., Terasawa K., Mech. Ageing Dev., 111, 155-173 (1999).

5) Zhang S., Murakami Y., Tohda M., Matsumoto K., Sakakibara I., Takayama H., Aimi N., Watanabe H., J. Trad. Med., 19, 28-36 (2002).

6) Gotz M. E., Kunig G., Riederer P., Youdim M. B., Pharmacol. Ther, 63, 37-122 (1994).

7) Sack C. A., Socci D. J., Crandall B. M., Arendash G. W., Neurosci. Lett., 205, 181-184 (1996).

8) Shukitt-Hale B., Erat S. A., Joseph J. A., Free Radic. Biol. Med., 24, 1149-1158 (1998).

9) Lin J. M., Lin C. C., Chen M. F., Ujiie T., Takada A., Am. J. Chin. Med., 23, 43-51 (1995).

10) Liu J., Mori A., Neuropharmacology, 3, 1287-1298 (1992).

11) Sekiya N., Shimada Y., Shibahara N., Takagi S., Yokoyama K., Kasahara Y., Sakakibara I., Terasawa K., Phytomedicine, 9, 636-640 (2002).

12) Aimi N., Shito T., Fukushima K., Itai Y., Aoyama C., Kunisawa K., Sakai S., Haginiwa J., Yamasaki K., Chem. Pharm. Bull., 30, 40464051 (1982).

13) Shimada Y., Goto H., Kogure T., Shibahara N., Sakakibara I., Sasaki
H., Terasawa K., Am. J. Chin. Med., 29, 173-180 (2001).

14) Qi Z., Watanabe H., Murakami Y., Tohda M., Matsumoto K., J. Trad. Med., 19, 153-157 (2002).

15) Tanaka K., Fujita N., Yoshioka M., Ogawa N., Brain Res., 889, 225 228 (2001).

16) Mahakunakorn P., Tohda M., Murakami Y., Matsumoto K., Watanabe H., Vajarakupta O., Biol. Pharm. Bull., 26, 725-728 (2003).

17) Buege J. A., Aust S. D., Methods Enzymol., 52, 302-310 (1978).

18) Nagai T., Inoue R., Inoue H., Suzuki N., Food Chem., 80, 29-33 (2003).

19) Fontana M., Mosca L., Rosei M. A., Biochem. Pharmacol., 61, 12531257 (2001).

20) Elizabeth K., Rao M. N. A., Int. J. Pharmaceut., 58, 237-240 (1990).

21) Lapenna D., Ciofani G., Festi D., Neri M., Pierdomenico S. D., Giamberardino M. A., Cuccurullo F., Biochem. Pharmacol., 64, 16611667 (2002).

22) Hyslop P. A., Hinshaw D. B., Schraufstatter I. U., Sklar L. A., Spragg R. G., Cochrane C. G., J. Cell Physiol., 129, 356-366 (1986).

23) Hyslop P. A., Hinshaw D. B., Halsey W. A., Jr., Schraufstatter I. U., Sauerheber R. D., Spragg R. G., Jackson J. H., Cochrane C. G., J. Biol. Chem., 263, 1665-1675 (1988).

24) Barbouti A., Doulias P., Nousis L., Tenopoulou M., Galaris D., Free Radic. Biol. Med., 33, 691-702 (2002).

25) Chandra J., Samali A., Orrenius S., Free Radic. Biol. Med., 29, 323 333 (2000).

26) Nardini M., Pisu P., Gentili V., Natella F., Di Felice M., Piccolella E., Scaccini C., Free Radic. Biol. Med., 25, 1098-1105 (1998).

27) Ishige K., Schubert D., Sagara Y., Free Radic. Biol. Med., 30, 433446 (2001).

28) Roig R., Cascon E., Arola L., Blade C., Salvado M. J., Biochim. Biophys. Acta, 1572, 25-30 (2002).

29) Gao J., Igarashi K., Nukina M., Chem. Pharm. Bull., 48, 1075-1078 (2000).

30) Halliwell B., Gutteridge J. M. C., Aruoma O. I., Anal. Biochem., 165, 215-219 (1987).

31) Smith C., Halliwell B., Aruoma O. I., Food Chem. Toxicol., 30, 483489 (1992).

32) Aruoma O. I., Mutat. Res., 523-524, 9-20 (2003).

33) Saija A., Tomaino A., Trombetta D., Pellegrino M. L., Tita B., Caruso S., Castelli F., Eur. J. Pharm. Biopharm., 53, 209-215 (2002).

34) Gutierrez M. E., Garcia A. F., Africa de Madariaga M., Sagrista M. L., Casado F. J., Mora M., Life Sci., 72, 2337-2360 (2003).

35) Bastianetto S., Quirion R., Neurobiol. Aging., 23, 891-897 (2002).

36) Nie G., Jin C., Cao Y., Shen S., Zhao B., Arch. Biochem. Biophys., 397, 84-90 (2002). 